\title{
Model for Nitrification in Activated Sludge Process
}

\author{
Lambertus Lijklema ${ }^{1}$ \\ Department of Environmental Sciences and Engineering, University of North Carolina, Chapel Hill, N.C. 27514
}

A model for the simulation of nitrification in activated sludge is presented and calculations are compared with experimental results from different sources. The role of protozoa and the influence of reactor type and of diurnal variations in flow and strength of the sewage are considered. Favorable conditions for nitrification are low rates of sludge wasting, high temperatures, plug-flow-type reactors and constant operational conditions. Protozoa preying on bacteria decrease the maximum allowable load at which nitrification still occurs. The hydraulic detention time in the aeration tank does not directly affect the degree of nitrification but short detention times may cause failure of the settling tank to separate the sludge from the effluent and hence increase the rate of sludge wasting. Under variable flow conditions, however, a long detention time is favorable for nitrification.

The need to reduce the discharge of nutrients and oxygen-demanding materials into surface waters has caused considerable interest in the biochemical oxidation of ammonia. The main nitrifying organisms involved in the activated sludge process are Nitrosomonas, which oxidizes ammonia to nitrite, and Nitrobacter, which completes the oxidation to nitrate. Important characteristics of these autotrophic organisms are their low growth rates and the strong dependency of these growth rates upon temperature. Since Nitrosomonas is generally rate-limiting, the growth rate of this organism determines the feasible operating conditions for nitrification. Downing et al. (1964) developed a model based upon the concept that the relative growth of nitrifiers should be at least equal to the relative growth of the total biomass in the activated sludge if consistent nitrification is to take place.

In the mass balance for nitrifiers in an activated sludge unit, however, not only terms for growth and wasting of biomass should be considered, but also terms for decay and consumption of nitrifiers by predators. Hence, an attempt was made to incorporate the growth of predators in the present model.

Whereas pilot plants are generally completely mixed tank reactors, field plants often are plug flow reactors with a certain degree of dispersion (Murphy and Timpany, 1967). The efficiency of real reactors lies between the limits set by completely mixed reactors and plug flow reactors; both types were simulated in this research.

Pilot plants and laboratory units generally are fed with a constant flow of influent, often also of constant composition. It was, therefore, considered useful to simulate the effect of diurnal variations in strength and flow as encountered in practice.

\section{Nitrification Model}

Three different organisms are modeled. All the heterotrophic organisms are represented by one species with Monod growth characteristics. The second organism is

1Present address, Twente University of Technology, P. O. Box 217. Enschede, The Netherlands.
Nitrosomonas, also growing according to Monod's conception at a rate

$$
\mu=\left(\mu_{\max } \times S\right) /\left(K_{s}+S\right)
$$

In this equation, $S$ represents the substrate concentration and $K_{s}$ the saturation constant, the value of which can be measured as the substrate concentration at which the growth rate is half the maximum growth rate.

The third organism modeled is a predator, representing all the protozoa and rotifers that may be present in activated sludge.

The heterotrophic bacteria feed upon the organic carbon, measured in terms of COD, of the influent while the nitrifiers utilize the ammonia-nitrogen as their energy source. It is assumed that the organic nitrogen in the influent satisfies the nitrogen demand of the heterotrophs. Data concerning growth rates, saturation constants and yields were obtained from the literature (Painter, 1970; Lawrence and McCarty, 1970) and expressed in the units $\mathrm{mg}$ COD, mg N, liter, and hours. Unless stated otherwise, the values used at $20^{\circ} \mathrm{C}$ are those shown in Table $\mathrm{I}$.

Whereas for modeling of heterotrophic bacteria and Nitrosomonas, sufficient accurate literature data are available, the data on protozoa are mostly qualitative or not directly applicable to activated sludge. Protozoa feed on soluble substrates, heterotrophic bacteria, nitrifiers, and also on other protozoa. The growth on soluble substrates can be neglected since the saturation constant is much higher than this value for bacteria and also high compared to the substrate concentrations generally encountered in sewage. It is assumed that the microorganisms in the sludge are consumed by predators in proportion to their weight fraction in the biomass. However, certain protozoa tend to become selective with respect to their food source (Barnes, 1963) and this would be of considerable consequence if nitrifying bacteria were preferred or rejected by the dominant protozoan population.

The maximum growth rate of free swimming ciliates feeding upon dispersed bacteria has been shown to be in the order of magnitude of the maximum growth rate of bacteria (Straskrabova and Legner, 1969; Curds and Cockburn, 1968, 1971). Hence the nonflocculated bacteria will be consumed at a high rate. When there exists a dynamic equilibrium:

$$
\text { Bacteria in sludge } \rightleftarrows \text { dispersed bacteria }
$$

in which the rate of dispersion is proportional to the bacterial mass in the sludge, a growth of predators proportional to the bacterial mass can be assumed:

$$
\text { growth }=\text { constant } \times \text { biomass }
$$

Parker et al. (1972) have developed a model for floc breakup which predicts that the majority of the sludge flocs is indeed subject to erosion. The approach in this research neglects the contribution of the dispersed bacteria in the influent. This seems reasonable at the low loading range in which nitrification occurs.

In a normal sludge, not subject to extremely high load- 
Table I. Constants for Nitrification Model at $20^{\circ} \mathrm{C}$

\begin{tabular}{|c|c|c|c|c|c|}
\hline Organism & Substrate & Max. growth rate $\mathrm{hr}^{-1}$ & $\begin{array}{l}\text { Decay rate } \\
\text { constant } h r^{-1}\end{array}$ & $\begin{array}{l}\text { Saturation constant, } \\
\text { mg of substrate. } 1^{-1}\end{array}$ & $\begin{array}{l}\text { Yield, mg cell } \\
\text { COD } / \mathrm{mg} \\
\text { substrate }\end{array}$ \\
\hline $\begin{array}{c}\text { Heterotrophic } \\
\text { bacteria }\end{array}$ & COD & 0.21 & 0.003 & 60 & 0.50 \\
\hline Nitrosomonas & $\mathrm{NH}_{4}-\mathrm{N}$ & 0.013 & 0.003 & 1 & 0.08 \\
\hline Predator & Bacteria & $0.010(+0.001)$ & 0.005 & Inert material & 0.55 \\
\hline
\end{tabular}

ing, the majority of protozoa are crawling and stalked ciliates (Hawkes, 1963). These organisms are concentrated in the sludge while free swimming ciliates are not. These sessile ciliates not only feed on free swimming bacteria but also consume particles of sludge flocs as can be observed under the microscope. In old flocs, the availability of food will probably be lower due to the accumulation of inorganic and inert material. To account for this, the growth of predators on sludge flocs is expressed as:

growth $=\mu_{\max } \times$ mass of predators $\times$

$$
\text { biomass/MLVSS }
$$

Biomass is the mass of all bacteria and predators and MLVSS = biomass + amount of inert material accumulated in the sludge. Equation 4 has the same form as the Monod equation, where the inert material takes the place of the saturation constant.

The total growth of the predators as modeled is obtained by adding Equations 3 and 4:

$$
\begin{aligned}
\text { Growth }= & 0.001 \text { (biomass })+ \\
& 0.01 \text { (mass of predators }) \text { (biomass } / \text { MLVSS })
\end{aligned}
$$

It is assumed that inert material is formed during the biochemical processes according to the scheme:

$$
\mathrm{COD} \rightarrow\left\{\begin{array}{l}
0.12 \text { Inert } \\
0.38 \text { Oxidized } \\
0.50 \text { Bacteria } \\
\text { Nitrifiers } \\
\text { Protozoa }
\end{array}\right\} \rightarrow\left\{\begin{array}{l}
0.10 \text { Inert } \\
0.35 \text { Oxidized } \\
0.55 \text { Protozoa }
\end{array}\right.
$$

The constants used in Equation 5 were arbitrarily chosen such that the weight fraction of predators in the sludge reached a maximum of about $10 \%$ of the MLVSS at loads of $0.2-0.3 \mathrm{~g} \mathrm{COD/g}$ cellular COD, day and decreased slowly at higher loads. This is the loading range of interest at $20^{\circ} \mathrm{C}$. The semiquantitative data of Curds and Cockburn (1970) on protozoan mass indicate this order of magnitude for the protozoan population.

Simulation of plug flow reactors was performed by following the sludge through the process. After initial feeding, all biological processes proceeded during the mixedliquor detention time; after this period, instantaneously a part of the sludge was wasted and COD and ammonia were added with the influent. Generally the return sludge flow was taken as $50 \%$ of the influent flow. When we start with initial assumed concentrations, the steady state for repetitive cycles was approached by an iteration procedure. The formulation for completely mixed reactors is based upon a mass balance for the organisms and substrates involved. The simulation language used is CSMP (Continuous System Modeling Program, IBM 1969). This language is suitable for use with a digital computer. De-

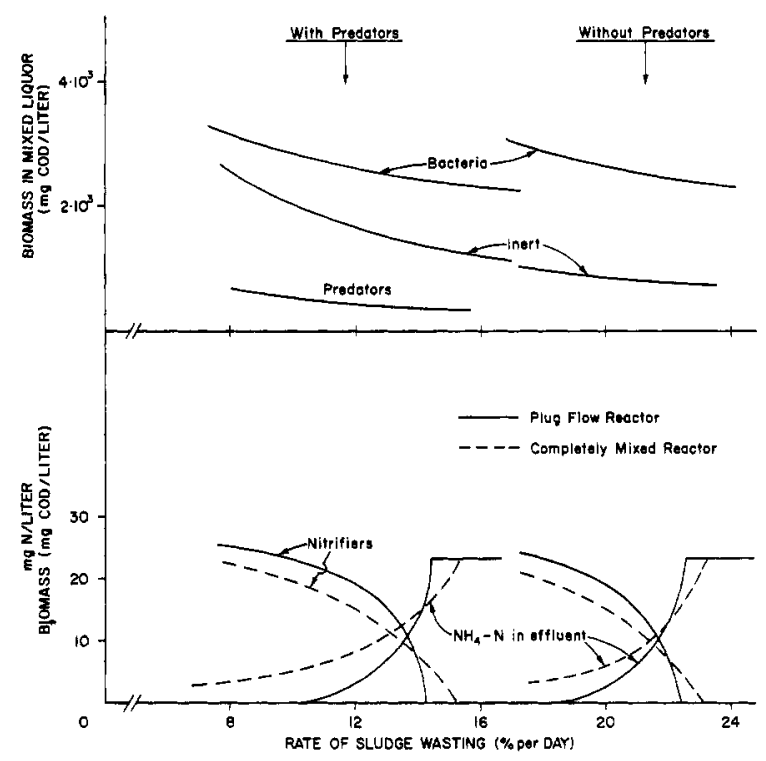

Figure 1. Simulation of nitrification in activated sludge Detention time mixed liquor, $5 \mathrm{hr}$

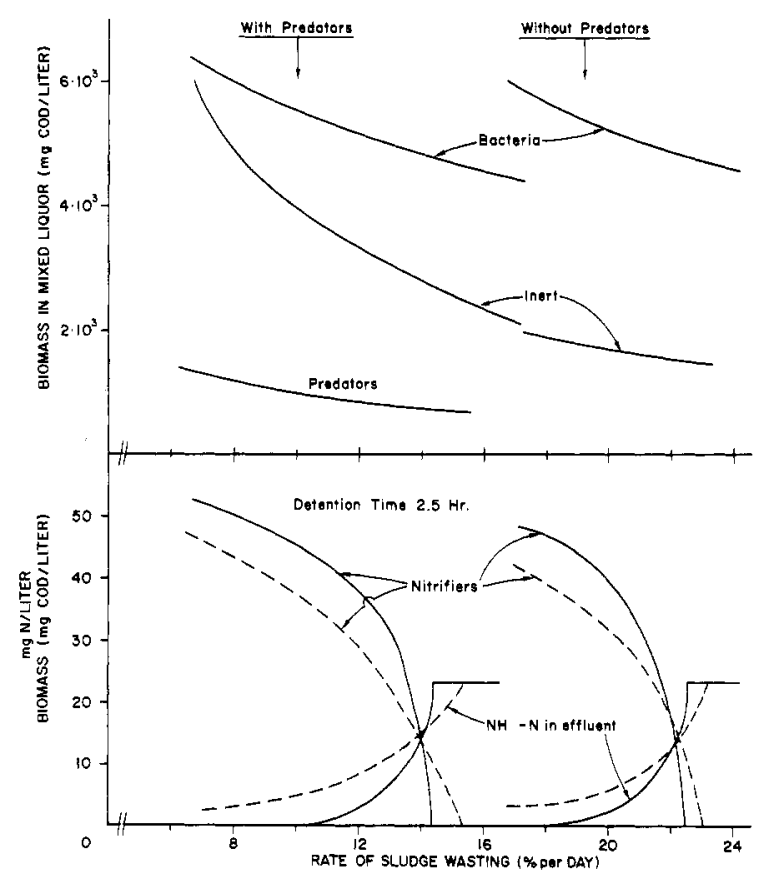

Figure 2. Simulation of nitrification in activated sludge Detention time mixed liquor, $2.5 \mathrm{hr}$ 
tails of the simulation programs are available from the author.

\section{Results of Simulations}

Simulations were run at mixed-liquor aeration times of $1,2.5,5$, and $10 \mathrm{hr}$ for both plug flow and completely mixed reactors. The same was done for a system without protozoa. In Figures 1 and 2, the results of simulations at 5 - and 2.5-hr detention time are shown. Since the concentration of heterotrophic bacteria, protozoa, and inert material differ only slightly for both reactor types in the region studied, these concentrations are represented by one curve. For nitrifying bacteria and the effluent ammonianitrogen concentration there is, however, an appreciable difference between the two reactor types. While essentially all the COD is removed in the plug flow reactor, there remains a very low concentration in the effluent of the completely mixed reactor.

The small amount of ammonia that passes unoxidized through a completely mixed reactor is responsible for the somewhat lower biomass of nitrifiers in such reactors as compared with plug flow systems. However, this difference disappears at increasing rates of sludge wasting and near the point of washout of nitrifiers, the reverse is true (Figures 1 and 2). Qualitatively, this can be explained as follows: when the critical rate of sludge wasting is approached, the biomass of nitrifiers decreases. As a result, the percentual increase in biomass along the length of a plug flow reactor increases. Hence, the relative difference between the average concentration of nitrifiers and the concentration at the end of the reactor also increases with increasing rates of wasting. In practice as well as in the model, sludge is wasted in plug flow processes from the end of the reactor with high concentrations of nitrifiers as compared with the average concentration of well-mixed reactors. Since proportionally more nitrifiers are removed from the plug flow system, the washout occurs at a lower rate of wasting.

Figures 1 and 2 show that reduction of the detention time causes a proportional increase in biomass for all species. At this point a new steady state is reached as can be seen by inspection of the mass balance:

$$
\text { Growth = decay }+ \text { predation + wasting }
$$

in which all terms increase proportionally to the reduction in hydraulic detention time. Hence the washout of nitrifiers occurs at the same rate of wasting, independent of

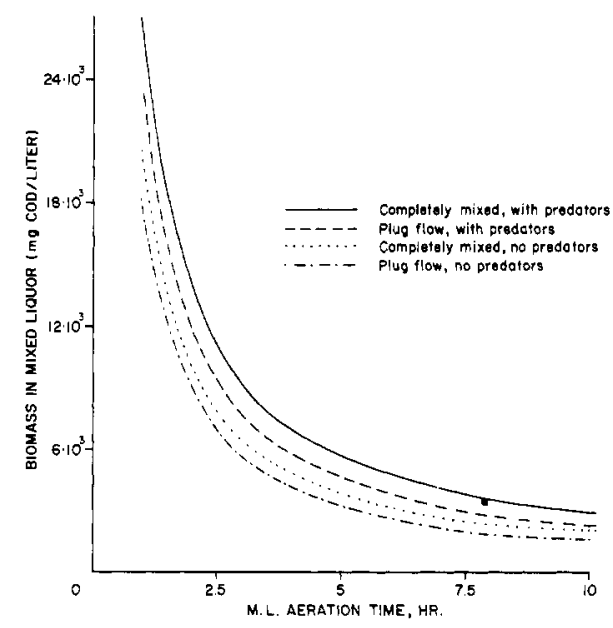

Figure 3. Minimum biomass to achieve $90 \%$ nitrification

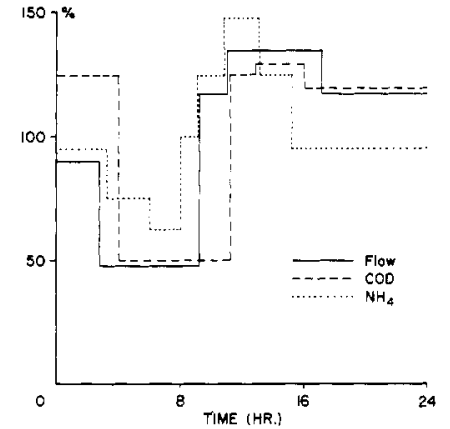

Figure 4. Diurnal variations in sewage

the hydraulic detention time. Since the rate of wasting is related to the solids retention time by

$$
\text { rate of wasting }(\% \text { per day })=100 / \theta
$$

where $\theta$ is the biological solids retention time; this observation can also be expressed in terms used by Lawrence and McCarty (1970). At steady state, the degree of nitrification depends on the solids retention time, not on the hydraulic detention time. As will be shown later, however, the hydraulic detention time is important in nonsteadystate situations.

The influent $\mathrm{COD}$ and $\mathrm{NH}_{4}-\mathrm{N}$ concentrations used in the simulations for Figures 1 and 2 were 450 and 23.5 $\mathrm{mg} / \mathrm{l}$, respectively. A higher $\mathrm{COD}$ or $\mathrm{NH}_{4}-\mathrm{N}$ concentration does not affect the critical rate of wasting for nitrifiers. The higher number of protozoa resulting from an increase in COD is compensated for by the smaller fraction of nitrifiers in the sludge. Hence, the term for predation is independent of the COD: $\mathrm{N}$ ratio in this model.

Figures 1 and 2 also demonstrate the importance of predators in reducing the apparent growth rate of nitrifiers and lowering the critical rate of sludge wasting for nitrification. The net growth constant as measured in sewage by Downing et al. includes this effect of protozoa. However, the protozoan population tends to vary with operating conditions in a manner different to that of nitrifying bacteria. This may in part explain a difference with Downing's model where either complete nitrification or none at all is found for steady state conditions. In the model presented here, a transition zone with partial nitrification exists.

Although this model offers only a rough description of the complicated ecological habits of protozoa and rotifers, the magnitude of their effect upon nitrification is of the order shown in the figures.

From Figures 1 and 2 and comparable data at other detention times, Figure 3 is derived. It shows the minimum MLVSS necessary to achieve $90 \%$ nitrification as a function of detention time for systems with and without predators and both reactor types. The MLVSS expressed in COD units will have nearly the same value as MLSS expressed in grams when $30 \%$ of the sludge is inorganic material. The shorter the detention time, the more sensitive nitrification tends to be for changes in detention times: a small decrease in detention time must be compensated for by a large increase in MLVSS. Since the concentrations in Figure 3 are proportional to the influent COD and since high suspended solids concentrations are difficult to maintain in activated sludge, the general experience is that nitrification does not occur when the COD of the sewage is high. Nitrification can be achieved in a second phase in such situations. This effect of organic loading is 


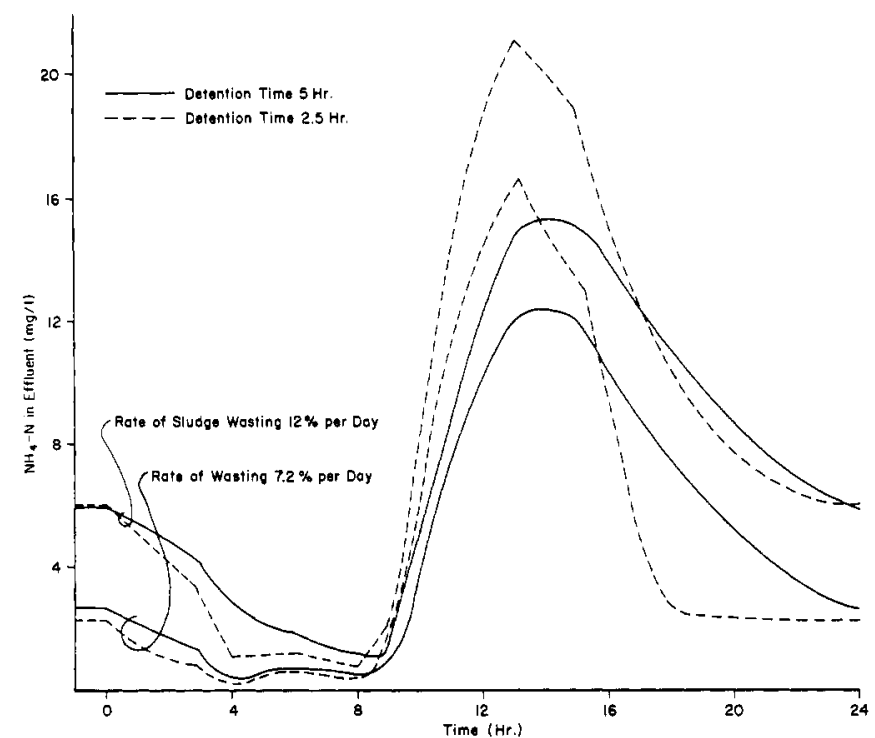

Figure 5. Simulation of diurnal effluent ammonium concentration

\begin{tabular}{|c|c|c|}
\hline Parameter-changed & $\begin{array}{c}\% \text { Increase in } \\
\text { load at which } 90 \% \\
\mathrm{NH}_{4} \text { removal } \\
\text { occurs } / \% \\
\text { increase in } \\
\text { parameter }\end{array}$ & $\begin{array}{c}\% \text { Increase in } \\
\text { load at which } 50 \% \\
\mathrm{NH}_{4} \text { removal } \\
\text { occurs } / \% \\
\text { increase in } \\
\text { parameter }\end{array}$ \\
\hline$\mu_{\max }$ nitrifier & +3.0 & +2.57 \\
\hline$K_{\text {sat }}$ nitrifier & -0.5 & -0.12 \\
\hline$K$ decay nitrifier & -0.83 & -0.45 \\
\hline$\mu_{\max }$ predators & -0.62 & -0.42 \\
\hline Yield predators & +0.52 & +0.30 \\
\hline$K$ decay predators & +0.2 & +0.1 \\
\hline
\end{tabular}

not due, however, to inhibition, but to the high sludge production (Downing et al., 1964).

The sensitivity of the model for the different parameters used was analyzed. Table II shows the percentage change in the load at which $90 \%$ or $50 \%$ of the influent ammonia is oxidized divided by the percentage change in the parameter studied. The effect of the other parameters was negligible. The load is expressed in $\mathrm{g}$ COD/g sludge COD, day.

The model is most sensitive to changes in the growth rate of the nitrifiers. Since this growth rate depends strongly upon temperature, the model is also sensitive to temperature. According to Painter (1970), the maximum growth rate of nitrifiers increases about $12 \% /{ }^{\circ} \mathrm{C}$. The saturation constant of Nitrosomonas, however, also increases strongly from $1 \mathrm{mg} \mathrm{N} / \mathrm{l}$. at $20^{\circ} \mathrm{C}$ to $10 \mathrm{mg} \mathrm{N} / \mathrm{l}$. at $30^{\circ} \mathrm{C}$ (Painter, 1970). This affects especially the removal of low concentrations of ammonia, as can be seen in Table II and also in the term $S /\left(K_{s}+S\right)$ of the growth rate expression.

The combined effect of an increase in temperature is no improvement or even deterioration of the $\mathrm{NH}_{4}$-removal capacity for high removal percentages and increasing improvement of nitrification at lower levels of $\mathrm{NH}_{4}$ - removal.

\section{Diurnal Variations}

Figure 4 shows an approximation of the daily variation in flow, COD, and $\mathrm{NH}_{4}$ concentration as observed in the sewage of Chapel Hill, N.C. (Hanson et al., 1970). Simu- lations using these approximations were run for one diurnal cycle. As initial conditions, the steady state situation with average flow and strength was used. Figure 5 shows the resulting $\mathrm{NH}_{4}-\mathrm{N}$ effluent concentration at two detention times and different rates of wasting. The wasting was kept proportional to the flow, a completely mixed reactor was modeled and the average COD and ammonium- $\mathrm{N}$ concentration of the influent were 450 and $23.5 \mathrm{mg} / \mathrm{l}$, respectively.

Figure 5 shows the beneficial effects of long detention times and low rates of wasting, but in all these cases, an appreciable amount of ammonia leaked through during the peak flow. It should be noted that the total loading of the reactor with COD and ammonia is higher than in the case of constant flow and concentrations, since the high concentrations coincide with high flows. The faster growing bacteria take advantage of this higher load by increasing in mass. The predators and nitrifiers, however, decrease in mass over the diurnal cycle, especially at high rates of wasting and low detention times. This means that, when other conditions remain constant, the diurnal variations cause a shift of the critical rates of wasting to lower values. Also, the critical rate of wasting will no longer be the same for all detention times, but lower for short detention times. It should be noted that in practice the peaks in flow and in ammonia and COD concentrations are shifted depending upon the detention time of the sewage in the primary settling tank. An increased $\mathrm{NH}_{4}-\mathrm{N}$ concentration has to pass the primary settling tank before it reaches the aeration tank while the response to a higher flow is instantaneous.

A practical conclusion can be drawn from the simulated effects of diurnal variations. The supernatant of digesters, which has a high ammonia concentration, is generally combined with the influent of activated sludge plants. By treating this supernatant during low flow times the ammonia is distributed more evenly, resulting in a higher biomass of nitrifiers and enhanced overall nitrification.

\section{Comparison with Experimental Results}

Data from three different sources were compared with the results from simulations. Johnson and Schroepfer (1964) presented experimental data at $20^{\circ} \mathrm{C}$; the data from the UNC Wastewater Research Center at Chapel Hill

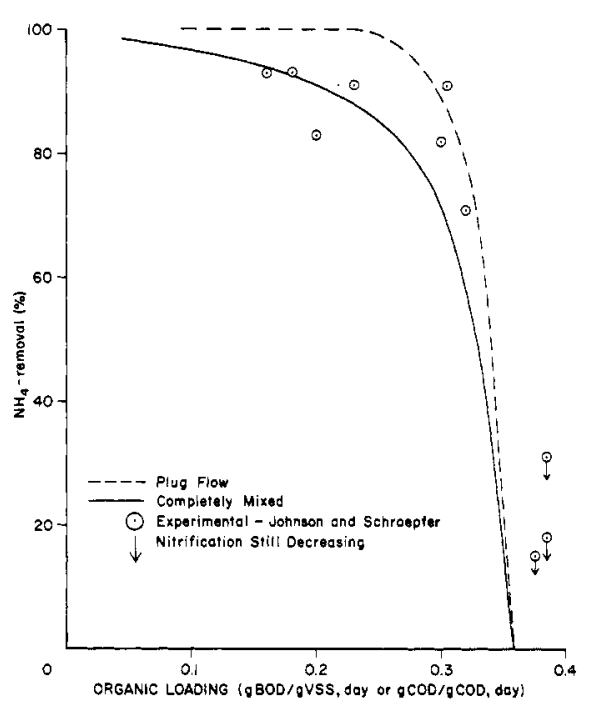

Figure 6. Nitrification as a function of organic loading at $20^{\circ} \mathrm{C}$ 
(Francisco et al., 1971) were measured at $25^{\circ} \mathrm{C}$; while the observations of Mechalas et al. (1970) were made at $29^{\circ} \mathrm{C}$.

Johnson and Schroepfer worked with a synthetic waste under constant flow conditions in a completely mixed tank. Their results are expressed in terms of load factor ( $g$ $\mathrm{BOD} / \mathrm{g}$ VSS, day). From their experiments, they concluded that the detention time in itself is not the decisive parameter to describe favorable or unfavorable conditions for nitrification. This is in agreement with the results of simulations with constant flow conditions (Figures 1 and 2).

Figure 6 shows as a result of simulations the nitrification as a function of the load. The load parameter $\mathrm{g}$ $\mathrm{COD} / \mathrm{g}$ sludge COD, day is estimated to be about the same as the expression used by Johnson and Schroepfer, although for an exact comparison the effluent COD in their experiments should be known. In agreement with the model, these authors found that nitrification disappeared at loadings over $0.35 \mathrm{~g} \mathrm{BOD} / \mathrm{g}$ VSS, day. The experimental conditions for the nitrification experiments at the UNC Wastewater Research Center are described by Francisco et al. (1971). During part of the experiments, the rate of wasting was kept constant, allowing a comparison with the model presented. Figure 7 shows the results. The growth rate constant for Nitrosomonas used was 0.024 $\mathrm{hr}^{-1}$, the approximate value at $25^{\circ} \mathrm{C}$. In several experiments, a high suspended solids concentration was observed in the effluent as indicated in the figure. The rate of wasting in these experiments is essentially unknown. The remaining observations are in reasonable agreement with the results of the simulation which shows the maximum theoretical ammonia removal. The experimental conditions are quite different from a normal activated sludge plant since the influent used was the relatively low $\mathrm{BOD}$ effluent of a high rate trickling filter.

Mechalas et al. (1970) performed their nitrification studies at $29^{\circ} \mathrm{C}$ with stored settled municipal sewage and presented their results in terms of percentage oxidation of total Kjeldahl-Nitrogen as a function of load (g COD $/ \mathrm{g}$ MLVSS, day). The values used for the different parameters in the simulations at this higher temperature are given in Table III.

To convert the load parameter $\mathrm{g}$ COD/g sludge COD, day into the units used by Mechalas et al., a conversion factor of 1.41 was used, based upon a cellular composition of $\mathrm{C}_{5} \mathrm{H}_{7} \mathrm{NO}_{2}$. Actually the cellular composition and-to a lesser degree-the conversion factor are a function of load-

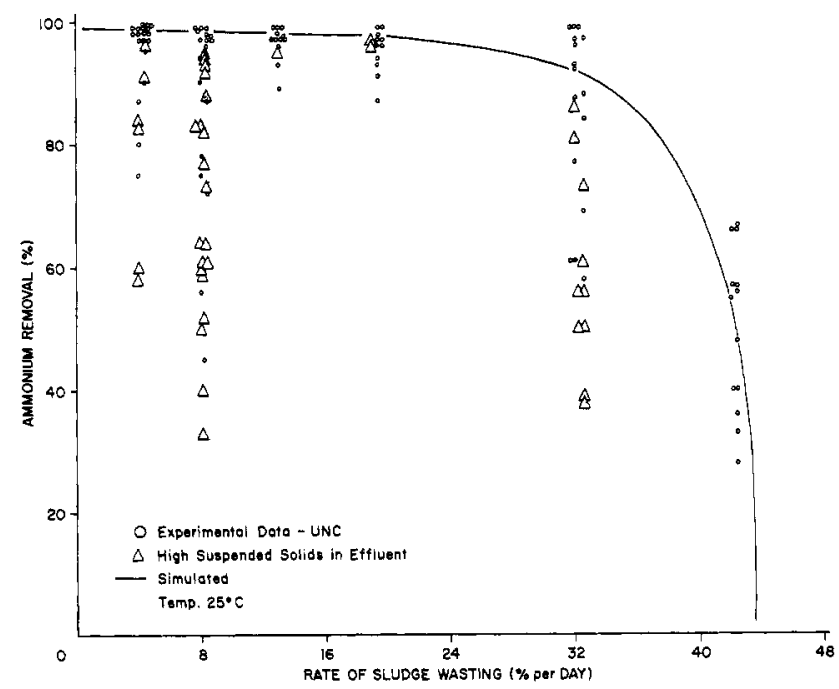

Figure 7. Nitrification of trickling filter effluent

\section{Table III. Constants for Nitrification Model at $29^{\circ} \mathrm{C}$}

\begin{tabular}{|c|c|c|c|}
\hline & $\underset{\mathrm{hr}^{-1}}{\operatorname{Max}}$ growth rate & $\begin{array}{l}\text { Decay } \\
\text { rate, } \mathrm{hr}^{-1}\end{array}$ & $\begin{array}{c}\text { Saturation } \\
\text { constant, } \\
\text { mg } / 1 .\end{array}$ \\
\hline Heterotrophs & 0.31 & 0.005 & 60 \\
\hline Predators & $0.016(+0.001)$ & 0.007 & Inert \\
\hline Nitrosomonas & 0.039 & 0.005 & 8 \\
\hline
\end{tabular}

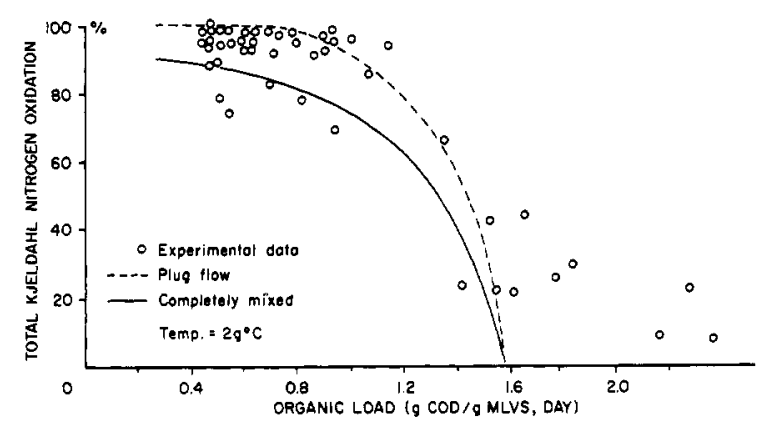

Figure 8. Nitrification in fixed bed reactor

ing, but at least a reasonable approximation is obtained by this procedure. The results are shown in Figure 8 . Mechalas et al. used a reactor in which the microorganisms were not suspended in the sewage, but fixed to the surface of plastic rings. This reactor type is more like a trickling filter and not directly comparable with activated sludge. However, the short circuiting which is characteristic for completely mixed reactors will not occur. Figure 8 shows that the experimental results fit very well the curve calculated for a plug flow reactor.

\section{Conclusion}

The conceptual model as presented is capable of predicting fairly accurately the degree of nitrification in activated sludge under widely variable conditions.

The general experience concerning nitrification is that high temperatures, low organic loadings, plug flow, high suspended solids, constant operational conditions, and long detention times are either separately or in combination favorable. In this mass balance-based kinetic model, an attempt has been made to illustrate the effect of protozoa. The dynamic character of the model also enables prediction of the nitrification under variable operational conditions.

Although comparison of the model with experimental data shows a good agreement, this does not necessarily mean that the model itself is correct. It is possible that an error in one term (e.g., overestimation of the effect of predation) is compensated by an error in other terms (e.g., overestimation of the growth rate of nitrifiers). In application of the model this should be kept in mind.

The diurnal variations in flow and strength of sewage reduce the attainable degree of nitrification in activated sludge processes. This is in contrast with submerged filters which are reported to be rather insensitive to such variations (Haug and McCarty, 1971). However, in twostage biological processes where the nitrification is performed in a second stage activated sludge process, the adsorptive characteristics of the natural clay clinoptilolite may be used. A temporary high ammonia load will be adsorbed on this zeolite and the ammonia will be released 
during periods of low loading and used as an energy source by the microorganisms. When no sludge wasting is practiced, the clinoptilolite can be recycled continuously. (Patent proceedings have been initiated covering various applications of this process.) The complicated regeneration procedure with lime is not necessary in such an application of clinoptilolite.

Not considered in the model is the influence of $\mathrm{pH}$ upon nitrification. The acid production associated with nitrification may in itself cause a considerable decrease of $\mathrm{pH}$ in weakly buffered sewage. The author has also developed a dynamic model for the simulation of $\mathrm{pH}$ in activated sludge which can incorporate nitrification (Lijklema, 1972). By combining these two models, a more complete dynamic model can be obtained.

\section{Acknowledgment}

The author is grateful to Linda W. Little and Charles R. O'Melia for their stimulating comments.

\section{Literature Cited}

Barnes, R. D., "Invertebrate Zoology," P. Saunders, Philadelphia, Pa., 1963.

Curds, C. R. Cockburn, A., J Gen Microbiol., 54, 343-58 (1968).

Curds, C. R., Cockburn, A., ibid., 66, 95-108 (1971).

Curds, C. R., Cockburn, A., Water Res. 4, 237-49 (1970).

Downing, A. L., Painter, H. A., Knowles, G., J. Inst. Sewage Purification, 2, 130-158 (1964).
Francisco, D. E., Little, Linda W., Lamb, J. C., "Activated sludge modifications for enhancement of trickling filter plant performance," Department of Environmental Sciences and Engineering, ESE Publication No. 272, University of North Carolina, Chapel Hill, N.C., 1971.

Hanson, R. L., Walker, W. C., Brown, J. C., "Variations in Characteristics of Wastewater Influent at the Mason Farm Wastewater Treatment Plant, Chapel Hill, North Carolina," Department of Environmental Sciences and Engineering, ESE Publication No. 255, University of North Carolina, N.C., 1970.

Haug, R. T., McCarty, P. L., Annual Conference of the Water Pollution Control Federation, San Francisco, Calif., October 1971.

Hawkes, H. A., "The ecology of wastewater treatment," P. Pergamon Press, Ltd., Oxford, England, 1963.

International Business Machines Corp., Manual H-20-0367, fourth ed., 1969.

Johnson, W. K., Schroepfer, G. T., J. Water Pollut. Contr. Fed. 36, 1015-36 (1964)

Lawrence, A. W., McCarty, P. L., J. Sanit. Eng. Div., Amer. Soc. Civil Eng., 96, (SA3) 757-778 (1970).

Lijklema, L., Water Res., 6, 165-82 (1972)

Mechalas, B. J., Allen, P. M., Matyskiela, W. W., Water Pollut. Contr. Res. Ser. 17010 DRD 07/70, Department of the Interior, FWQA, 1970.

Murphy, K. L., Timpany, P. L., J. Sanit. Eng. Div., Amer. Soc. Civil Eng., 93 (SA5), 1-15, (1967).

Painter, H. A., Water Res., 4, 393-450 (1970).

Parker, D. S., Kaufman, W. J., Jenkins, D., J. Sanit. Eng. Div. Amer. Soc. Civil Eng., 98, (SA1) 79-99 (1972).

Straskrabova, Vera, Legner, M., Advan. Water Pollut. Res., Proceedings of the 4th International Conference, Prague, 1969.

Received for review June 19, 1972. Accepted December 19, 1972

\title{
Ferromagnetic Sorbents for Oil Spill Recovery and Control
}

\author{
J. E. Turbeville
}

Department of Physics, University of South Florida, Tampa, Fla. 33620

- Buoyant, ferromagnetic, sorbent particles with an affinity for oil will transform a maritime oil spill into a magnetizable surface film whereby it is possible, with suitable magnetic equipment, to control and recover any oil so treated. Laboratory experiments were conducted to develop ferromagnetic sorbents and study their properties when combined with various test oils. These experiments provide information on the magnetic advantage of such a recovery concept. This advantage is expressed as gain and is shown to increase as the viscosity of the oils under test decreases. A drain rate equation was also obtained from the experiments and is incorporated with results obtained from experimental tests with a model oil recovery unit. Together, they provide a general expression for recovery rates which can be used as a scaling equation for larger units. Prototype floating magnetic grid units were constructed and tested for possible use as "magnetic nets" or "magnetic barriers." The advantages gained by the addition of magnetic principles to sorbent systems of oil spill recovery could possibly outweigh the disadvantages of sorbents now in general use.

Treatment of a maritime oil spill with sorbent particles which are buoyant, ferromagnetic, and water resistant will transform the spill into a magnetizable surface film whereby it is possible, with suitable magnetic fields, to trap and contain the oil or remove it directly from the water surface.
If the oil is a low-grade high-density type fuel oil, the added bouyancy of the ferromagnetic sorbent will tend to support the oil and keep it from sinking, should the water density change from that of seawater to a degree of brackishness where sinking would normally occur.

Buoyant ferromagnetic sorbents and the associated magnetic containment and collection devices offer a technique for oil spill recovery and control that is indeed unique.

The ideas and methods conceived and tested are outlined below.

Ferromagnetic sorbents were developed from commercially available products and are classified as either adsorbent or absorbent.

Laboratory studies were made with various oil mixtures to determine the holding characteristics of the permanent magnetic material and the ferromagnetic sorbents which are used in combination to lift oil from the water surface on an oil recovery test unit.

Tests were conducted with the oil recovery unit in a 10 -ft tank to establish scale factors and oil recovery rates.

Tests were made of prototype floating magnetic grids intended for use in the construction of containment barriers or magnetic nets.

Ferromagnetic Sorbents. A commercially available polystyrene bead (Dylite manufactured by Sinclair-Koppers) was used to produce the ferromagnetic adsorbent. The material has a density of $40 \mathrm{lb} / \mathrm{ft}^{3}$ (PCF) in its unexpanded form and, after treatment in a steam expander, 